\title{
Fontanus Publications
}

\author{
The Fontanus Monograph Series \\ and the annual journal Fontanus, \\ published by the McGill University Libraries, \\ are devoted to the exploration \\ and presentation of the collections of the \\ McGill University libraries, museums \\ and archives. \\ General Editor: Hans Möller \\ Associate Editor: Richard Virr
}

\section{FONTANUS PUBLICATIONS}

FONTANUS (journal)

\begin{tabular}{|c|c|}
\hline \multicolumn{2}{|c|}{ Prices } \\
\hline Inst. & Indiv. \\
\hline$\$ 25$ & $\$ 15$ \\
\hline 25 & 15 \\
\hline 30 & 20 \\
\hline 30 & 20 \\
\hline 35 & 25 \\
\hline 30 & 20 \\
\hline 30 & 20 \\
\hline
\end{tabular}

\section{FonTANUS MONOGRaPH SERIES}

I Adam Gacek, Arabic Manuscripts in the Libraries of McGill University, Union Catalogue 1991

II Calvin Evans, Soren Kierkegaard Bibliographies: Remnants 1944-1980 and

Multi-Media, 1925-1991

III Barbara Lawson, Collected Curios: Missionary Tales from the South Seas

IV John Hobbins, On the Edge of Greatness: The Diaries of John Humphrey,

Orders may be placed at:

Office of the Director of Libraries

3459 McTavish Street

Montreal, Quebec

H3A 1Y1 